\title{
Postawa społeczeństwa wobec organizmów modyfikowanych genetycznie (GM0) w Polsce - na przykładzie wybranych grup osób
}

\author{
Public Perception of Genetically Modified Organisms (GMOs) in Poland Based on the Samples of \\ Selected Groups of People
}

\author{
Justyna Anna Nowakowska ${ }^{1}$, Daria Berezovska ${ }^{2}$, Aleksandra Szulińska ${ }^{3}$ \\ ${ }^{1}$ Instytut Nauk Biologicznych, Uniwersytet Kardynała Stefana Wyszyńskiego w Warszawie \\ ${ }^{2}$ Wydział Farmaceutyczny, Uniwersytet Medyczny w Warszawie \\ 3 Wydział Biologii i Nauk o Środowisku, Uniwersytet Kardynała Stefana Wyszyńskiego w Warszawie \\ ORCID: JAN https://orcid.org/0000-0001-5863-053X • j.nowakowska@uksw.edu.pl \\ Zgłoszono: 28.10.2020; zrecenzowano: 29.12.2020; zaakceptowano do druku: 14.01. 2021
}

\begin{abstract}
Streszczenie: Poziom wiedzy społeczeństwa nt. GM0 stale się zmienia. W listopadzie i grudniu 2019 r. studenci UKSW w Warszawie przeprowadzili ankiety wśród 699 anonimowych respondentów na temat zastosowania produktów GM0 w codziennym życiu Polaków. Osoby ankietowane podzielono wg czterech kryteriów: płci, wieku, wykształcenia i miejsca zamieszkania z podziałem na miasto i wieś, zadając 7 pytań merytorycznych odnośnie do poziomu wiedzy i osobistego podejścia do konsumpcji produktów GMO. Analizę statystyczną wyników wykonano w programie STATISTICA 12. Wykazano, że w ostatnich latach rośnie wiedza mieszkańców w Polsce nt. GMO, ale obawy przed produktami genetycznie modyfikowanymi nadal występują u ponad połowy społeczeństwa. Większość kobiet obawia się GM0, zwraca większą uwagę na oznakowanie produktów zawierających GMO i nie podałaby ich swoim dzieciom. Osoby w wieku poniżej 20 lat są pozytywnie nastawione do GM0, natomiast osoby w wieku powyżej 35 lat obawiają się negatywnych skutków spożywania produktów GM0. Również większość osób mieszkających na wsi obawia się produktów GM0, opinia zaś mieszkańców miasta jest podzielona na dwie, prawie równe grupy: zarówno zwolenników, jak i przeciwników GM0. Różnice w odpowiedziach odnośnie obawy przed negatywnymi skutkami spożywania produktów zawierających GMO były statystycznie istotne ( $p<0,001)$ i wykazały większe obawy wśród osób zamieszkujących tereny wiejskie $(67 \%)$ niż u mieszkańców miast (49\%). Jednocześnie, prawie ten sam duży odsetek osób ze wsi i z miasta (67\%) był przychylny stosowaniu leków wyprodukowanych drogą inżynierii genetycznej $(p<0,01)$.
\end{abstract}

Słowa kluczowe: ankieta, GMO, opinia publiczna, Polska

\begin{abstract}
The present study investigated the level of knowledge and the attitude of citizens of Poland $(n=699)$, taking into account - sex, age, education, and the place of residence (city or countryside), towards the various uses of GMOs. The statistical analysis of the results was performed in STATISTICA 12. It has been shown that the knowledge of inhabitants about GMOs in Poland is growing, but the fear of genetically modified products is still present in over half of the population. Most women are concerned about GMOs, and pay more attention to the labelling of GMO products, but would not give them to their children. People under the age of 20 have a positive attitude towards GMOs, while people over the age of 35, emphasise the negative effects of consuming GMO products. Most people living in the countryside are afraid of GMO products, and the opinion of city residents is divided into two almost equal groups: both supporters and opponents of GMOs. Differences in responses to the fear of the negative effects of consuming GMO products were
\end{abstract}


statistically significant $(p<0.001)$, and revealed that greater concern was present among people living in rural areas $(67 \%)$, than among urban residents (49\%). At the same time, almost an equal number of rural and urban residents $(67 \%)$ were favourable to the use of genetically engineered drugs $(p<0.01)$.

Keywords: consumers' acceptance, GM0, public opinion, Poland

\section{Wstęp}

Nowoczesna inżynieria genetyczna jest stosunkowo pionierską dziedziną nauk biologicznych, która zajmuje się m.in. procesami ukierunkowanej wymiany genów między organizmami przy pomocy metod biotechnologicznych. W związku z tym, że jest to stosunkowo nowa gałąź nauki, społeczny odbiór organizmów posiadających zmieniony genom jest często negatywny, choć można zaobserwować powolny trend w kierunku akceptacji wykorzystania GMO w niektórych sektorach przemysłu, zwłaszcza modyfikacji, które niosą korzyści dla życia i zdrowia. Pierwsze organizmy genetycznie modyfikowane (genetically modified organisms, GMO) powstały w latach 70. XX w. i od tej pory są powszechnie obecne we współczesnym rolnictwie, przemyśle spożywczym, farmakologii i medycynie na całym świecie (Jefferson et al. 2015, 407-416; Kamle et al. 2017, 219).

Termin GMO dotyczy organizmów, które powstały w wyniku modyfikacji ich genomu za pomocą technik inżynierii genetycznej polegających głównie na wprowadzeniu do genomu biorcy (najczęściej bakterii, grzybów, roślin i zwierząt) sekwencji DNA (transgenu) w celu uzyskania nowych cech ilościowych lub jakościowych. Przed transformacją genetyczną rośliny tworzony jest tzw. konstrukt genowy, który na ogół składa się z kilku podstawowych elementów, a mianowicie: sekwencji promotorowych (np. promotora z wirusa mozaiki kalafiora - pCaMV35S, lub promotora syntazy nopalinowej - pNOS), sekwencji kodujących białka, które ulegną ekspresji w komórkach biorcy, oraz sekwencji terminatorowych (np. tNOS). Całość sklonowana jest w odcinku transferowego DNA (T-DNA) plazmidu bakteryjnego Agrobacterium tumefaciens (L.) mikroorganizmu, który przez naturalny proces infekcji roślin przekaże sztucznie utworzony konstrukt genowy do komórki roślinnej (Liu et al. 2020, 106775).

Wprowadzenie obcego genu do genomu biorcy może być również wykonane przy użyciu elektroporacji ściany komórkowej pod wpływem szoku elektrycznego lub degradacji ściany komórkowej za pomocą substancji chemicznych, np. glikolu polietylenowego (PEG) w przypadku roślinnych protoplastów (Kamle et al. 2017, 219; Nester 20o8; Mathur i Koncz 1998, 267-276). Proces transformacji roślin za pomocą $A$. tumefaciens składa się z pięciu podstawowych etapów, a mianowicie: 1) izolacji wybranego genu z organizmu dawcy; 2) klonowania genu w plazmidzie Ti/Ri; 3) wprowadzenia plazmidu zawierającego T-DNA do Agrobacterium; 4) infekcji komórek roślinnych oraz 5) integracji T-DNA z genomem rośliny (Linkiewicz et al. 2012a, 843-855). Warto nadmienić, że oprócz konstruktu z genem docelowym w plazmidach bakteryjnych transferowane są również geny reporterowe oraz markerowe, jak np. nptII, który koduje białko odporności na kanamycynę, gen uidA kodujący glukuronidazę, lub gen białka zielonej fluorescencji $g f p$. Geny te umożliwiają wczesną selekcję transformowanych komórek w trakcie hodowli na pożywkach selekcyjnych in vitro.

Transformacja komórek zwierzęcych jest bardziej złożona i polega głównie na wprowadzeniu nowego genu drogą mikroiniekcji do komórek rozrodczych biorcy. Po przygotowaniu konstruktu $\mathrm{z}$ transgenem w plazmidach bakteryjnych, następuje proces mikroiniekcji komórek rozrodczych biorcy (zwierzęcia), a następnie przeprowadzana 
jest selekcja pozytywnych transformantów, czyli komórek które zintegrowały obcy gen z genomem gospodarza.

Począwszy od sektora rolno-spożywczego, po sektor farmaceutyczny i medyczny, konsument ma obecnie styczność z produktami, które zostały wytworzone na drodze inżynierii genetycznej. W rolnictwie, hodowane są odmiany gatunków uprawnych, tj. kukurydza MON810 odporna na omacnicę prosowiankę (Ostrinia nubilalis Hübner) i odmiana A5547-127 transgenicznej soi (Glycine max L.) o zwiększonej tolerancji na glifosat, aktywny składnik herbicydu Roundup (EFSA 2011, 2146; Linkiewicz et al. 2012b, 966-981). W światowym rolnictwie dominują odmiany kukurydzy, soi i rzepaku o zwiększonej odporności na aktywne związki herbicydów, co znacznie usprawnia eliminację chwastów w uprawach ww. gatunków, ale może też nieść ryzyko śladowej obecności środków chemicznej ochrony roślin w wytwarzanych produktach (Dyrektywa 2019). Na przykład, herbicyd Roundup (Monsanto, USA), uznany przez Światową Organizację Zdrowia (WHO) jako czynnik rakotwórczy dla człowieka ze względu na obecność glifosatu, jest coraz częściej wycofywany z gamy środków chemicznych stosowanych w uprawach.

W świetle Dyrektywy 2009/128/WE, rolnicy mają obowiązek przestrzegania zasad dobrej praktyki ochrony roślin, w tym rekomendowane jest stosowanie biologicznych środków ochrony roślin, a w wypadku stosowania chemicznych środków - należy przestrzegać okresów karencji przed sprzedażą końcowego produktu. Coraz częściej różne odmiany roślin uprawnych są wykorzystywane do produkcji substancji farmakologicznie czynnych, jak np. antygeny HBsAg wirusa zapalenia wątroby typu B syntetyzowane w liściach sałaty, lub przeciwzakrzepowa hirudyna w rzepaku, a nie jak dotąd pozyskiwana z pijawek lekarskich (Boothe et al. 1998, 172-181; Pniewski et al. 2011, 125-136).

Genetycznie modyfikowane mikroorganizmy są wytwarzane m.in. za pomocą
Escherichia coli (Escherich 1885), Bacillus thuringiensis (var. kurstaki), Bacillus subtilis (szczep RASFF2014.1249) i Pseudomonas fluorescens (szczep SBW 25). Te ostatnie mogą być nośnikami konstruktów genowych odpowiedzialnych za produkcję substancji farmakologicznie czynnych, w tym witamin i antybiotyków (Kues i Niemann 2004, 286-294; Fraiture et al. 2020, 106873). Do genetycznie modyfikowanych zwierząt zaliczane są głównie transgeniczne myszy, owce, krowy, kozy, świnie i króliki, które w większości na etapie eksperymentalnym produkują w gruczołach wydzielniczych (śliniankach, gruczołach mlecznych) substancje farmakologicznie czynne, tj. insulinę, interferony i czynniki krzepliwości krwi (Kleter i Kok 2010, 105-114; Linkiewicz et al. 2012b, 966-981).

Rosnący z roku na rok udział GMO w produktach rolno-spożywczych pochodzenia roślinnego i zwierzęcego oraz wyrobach farmaceutycznych i medycznych budzi wiele kontrowersji i obaw wśród szerokiego grona konsumentów, zarówno w Polsce, jak i na świecie (Marris 2001, 545-548; Bartoszewski 2012, 123-139). Obawy te mogą głównie wynikać z ubocznych skutków transformacji danego organizmu wraz z elementami konstruktów zawierającymi geny markerowe i reporterowe. Również sam typ genu docelowego może budzić kontrowersje wśród społeczeństwa, jak w przypadku genu kodującego hormon wzrostu $(\mathrm{GH})$ w transgenicznym łososiu wyprodukowanym przez firmę AquaBounty Technology (USA).

Od 2001 r. w Unii Europejskiej obowiązują regulacje prawne dotyczące bezpieczeństwa uwalniania do środowiska i obrotu GMO (Dyrektywa 2001; Rozporządzenie 2003; Dyrektywa 2015). W świetle obowiązujących przepisów genetycznie modyfikowana żywność może być importowana i dopuszczona do obrotu na rynku Unii Europejskiej pod warunkiem prawidłowego jej oznakowania pod kątem zawartości GMO.

Celem przeprowadzonego badania ankietowego było poznanie, w jaki sposób w ciągu ostatnich lat zmienił się poziom wiedzy 
polskiego społeczeństwa na temat współcześnie stosowanych modyfikacji genetycznych oraz w jakim stopniu opinia społeczna akceptuje powszechne stosowanie produktów zawierających GMO.

\section{Zasady przeprowadzenia ankiety}

W listopadzie i grudniu 2019 r. studenci ${ }^{1}$ z Uniwersytetu Kardynała Stefana Wyszyńskiego w Warszawie przeprowadzili ankietę wśród 699 anonimowych respondentów z różnych regionów Polski. Geograficzny rozkład respondentów obejmował głównie mieszkańców miasta Warszawy i województwa mazowieckiego (Wołomin, Otwock), ale też i Podlasia (Łomża, Białystok, Mońki, Sokołów Podlaski) oraz województwa łódzkiego (Łowicz, Pabianice). Zachodnią część kraju reprezentowali mieszkańcy Poznania, Wolsztyna i Mosiny. Tereny wiejskie dotyczyły w większości wschodniej (Dzierzby Szlacheckie, Nowe Lipiny, Żelków) i zachodniej (Czacz) części kraju. Osoby ankietowane podzielono według czterech kryteriów: płci, wieku, wykształcenia i miejsca zamieszkania (z podziałem na miasto i wieś). Respondentom zadawano 7 pytań merytorycznych, zarówno z zakresu poziomu wiedzy nt. GMO (1 pytanie), jak i osobistego podejścia do: a) organizmów o zmodyfikowanym genomie (2 pytania); b) konsumpcji produktów złożonych z GMO (2 pytania) oraz c) substancji wytwarzanych z GMO (2 pytania).

1 Studenci Biotechnologii z II roku studiów magistranckich na Wydziale Biologii i Nauk o Środowisku UKSW w Warszawie.
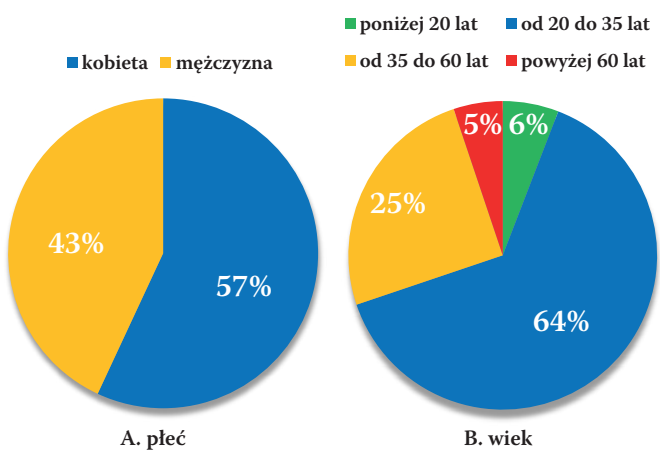

Odpowiedzi rozpatrywano pod kątem charakterystyki respondentów, a istotność różnic udzielanych odpowiedzi testowano za pomocą nieparametrycznego testu Chi kwadrat w programie STATISTICA 12 (StatSoft Polska), dla $\alpha=0,05 . \mathrm{W}$ przeprowadzonych testach, różnice między rozpatrywanymi kryteriami płci, wieku, wykształcenia i miejsca zamieszkania uznawano za istotne statystycznie przy poziomie istotności $\mathrm{p}<0,05$. Główną hipotezą badawczą było sprawdzenie, czy poziom wiedzy i akceptacja GMO są zależne od: 1) płci, 2) wieku, 3) poziomu wykształcenia i 4) miejsca zamieszkania respondentów wybranych w sposób całkowicie losowy.

\section{Wyniki}

\subsection{Demograficzna charakterystyka ankietowanych}

Większość respondentów ( $57 \%, \mathrm{n}=699$ ) stanowily kobiety w porównaniu do mężczyzn (43\%) (Wykres 1A). Były to osoby głównie $\mathrm{w}$ wieku od 20 do 35 lat (64\%), 25\% ankietowanych miało od 35 do 60 lat, natomiast 6\% i $5 \%$ stanowily osoby odpowiednio w wieku poniżej 2o lat i powyżej 6o lat (Wykres 1B). Większość ankietowanych miała wykształcenie wyższe (51\%) i średnie (28\%) oraz mieszkała w mieście (Wykres 1 C i 1D). Pozostałą grupę stanowiły osoby zamieszkujące wieś (17\%). Wśród ankietowanych znaleźli się też studenci $(19 \%)$ oraz osoby z wykształceniem podstawowym (2\%).

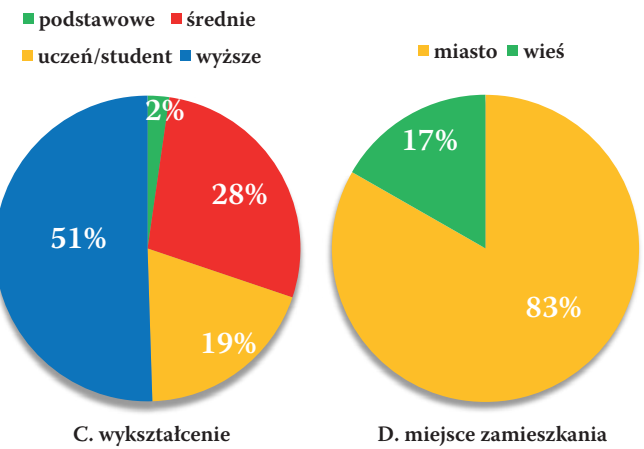

Wykres 1. Ogólna charakterystyka ankietowanych $(n=699)$ 


\subsection{Ogólna charakterystyka otrzymanych odpowiedzi}

Zauważono, że aż 94\% respondentów spotkało się z terminem "genetycznie modyfikowany organizm" (Wykres 2A), ale nie oznacza to, że poprawnie potrafili oni zdefiniować pojęcie GMO. Tylko 53\% respondentów wyrażało zgodę na uprawę roślin genetycznie zmodyfikowanych (Wykres 2B). Prawie $1 / 3$ ankietowanych była przeciwnych uprawom GMO, 16\% nie miało zaś ustalonego zdania w tej kwestii. Obowiązująca w Polsce ustawa z 1 stycznia 2019 r. ograniczająca stosowanie pasz wyprodukowanych z nasion transgenicznych roślin dla zwierząt gospodarskich i związane z tym wyższe koszty na rynku pasz mogą mieć wpływ na mniej drastyczny sprzeciw społeczeństwa w 2019 r. niż odnotowany w 2017 r. brak zgody u 70\% ankietowanych (Nowakowska 2018, 12-15; Ustawa 2019). Wprowadzona w życie ustawa miała na celu promocję krajowego rynku pasz produkowanych z rodzimych źródeł białka roślinnego.

Nieco więcej niż połowa (52\%) ankietowanych mieszkańców Polski obawia się negatywnych skutków spożywania produktów zawierających GMO i w konsekwencji 55\% ankietowanych nie podałoby produktów zawierających GMO swoim dzieciom (Wykres ${ }_{2} \mathrm{C}$ i $2 \mathrm{D}$ ). Liczba osób obawiających się skutków spożywania ww. produktów jest prawie o 20\% mniejsza w porównaniu do danych $\mathrm{z}$ badania opinii publicznej przeprowadzonych przez Twardowskiego (2008, 181-184) oraz Małyskę i in. (2012, 217-248). Zaskakujące jest, że mimo obaw przed negatywnymi skutkami spożywania produktów spożywczych z GMO prawie 54\% społeczeństwa nadal nie zwraca uwagi na oznakowanie kupowanych produktów spożywczych (Wykres 2E). Natomiast z możliwości stosowania leku wytworzonego drogą inżynierii genetycznej chętnie skorzystałoby aż $67 \%$ ankietowanych (Wykres 2F). Wynik ten przekłada się na wysokie (47\%) poparcie dla stosowania GMO do produkcji leków w przemyśle farmaceutycznym. Tym niemniej $25 \%$ osób nie wyraziło zgody na zastosowanie GMO do jakiegokolwiek celu (Wykres 2G). Tłumaczyć to może niewielka świadomość społeczeństwa, w jakim celu obecnie są stosowane organizmy modyfikowane genetycznie oraz w jakich produktach spożywczych i leczniczych się one znajdują.

\subsection{Wyniki zbiorcze odpowiedzi z podziałem na płeć}

Znajomość terminu GMO była na podobnym poziomie zarówno wśród kobiet (92\%), jak i mężczyzn (97\%). W sposób nieistotnie różny statystycznie $48 \%$ kobiet i $57 \%$ mężczyzn wyrażało swą zgodę na uprawę roślin GMO w rolnictwie $(\mathrm{p}=0,47)$. Odsetek kobiet i mężczyzn obawiających się negatywnych skutków spożywania produktów zawierających GMO różnił się w sposób nieistotny statystycznie (odpowiednio 56\% i $47 \%, p=0,17)$. Za to statystycznie istotne były różnice w odpowiedziach u kobiet (61\%) i mężczyzn (47\%) dotyczących niechęci podania swoim dzieciom produktów spożywczych zawierających GMO ( $\mathrm{p}=\mathrm{o}, 007)$. Również w sposób istotny grupa kobiet i mężczyzn zwracała uwagę na oznakowanie kupowanych produktów pod kątem zawartości w nich elementów GMO (odpowiednio: $51 \%$ i $37 \%, p<$ o,01). Różnica płci nie wpłynęła na statystycznie istotne poparcie respondentów dla korzystania z leków wyprodukowanych drogą inżynierii genetycznej (kobiety: 49\%, mężczyźni: 44\%, p = o,13). W podsumowaniu kobiety, w przeciwieństwie do mężczyzn, w większości obawiały się podania produktów GMO swoim dzieciom, co w sposób logiczny przełożyło się na większą uwagę kobiet zwracaną na oznakowanie produktów spożywczych pod kątem modyfikacji genetycznych. 
A. znajomość terminu GMO

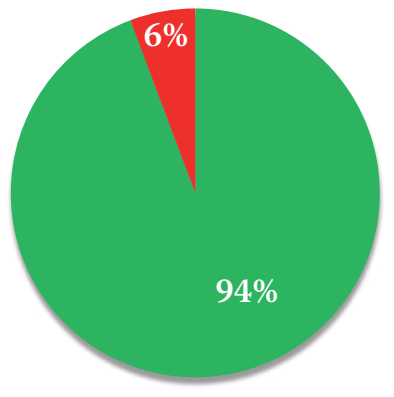

C. obawa przed negatywnymi skutkami spożywania produktów zawierających GMO

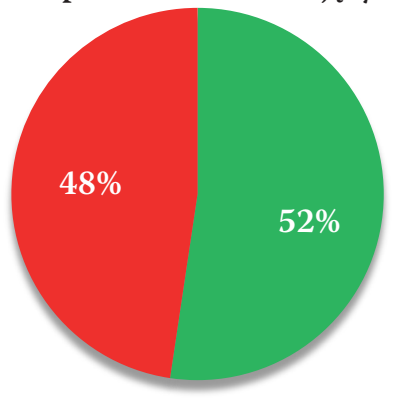

E. Zwracanie uwagi na oznakowanie kupowanych produktów pod kątem zawartości GMO

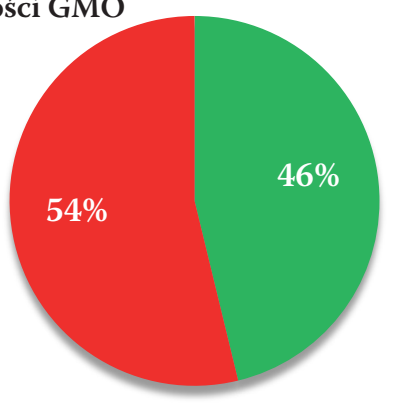

B. zgoda na uprawę roślin GMO w rolnictwie

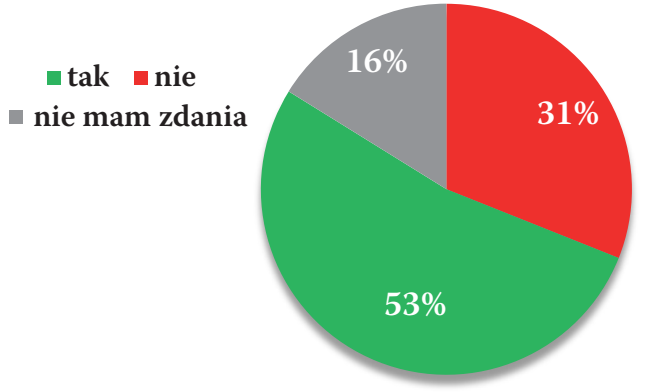

D. podanie swoim dzieciom produktów spożywczych zawierajacych GMO

atak $\backsim$ nie

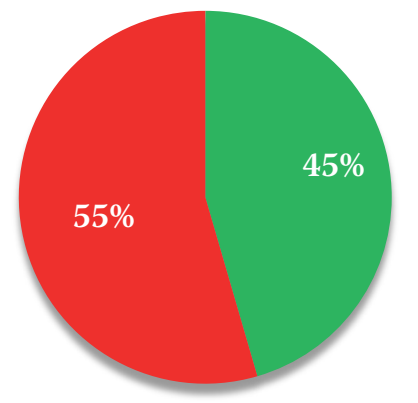

F. korzystanie z leków wyprodukowanych drogą inżynierii genetycznej

\section{ntak nie}

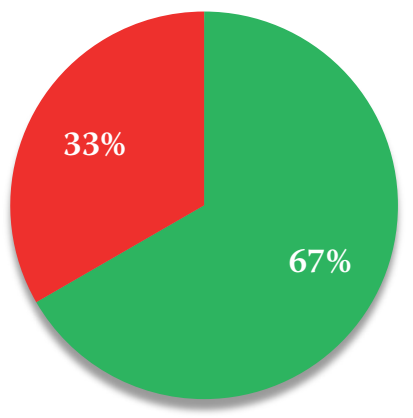

G. poparcie dla zastosowania GMO w róznych sektorach

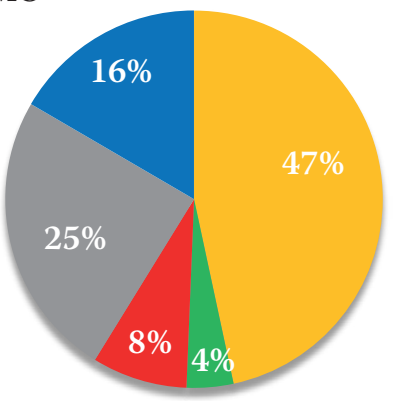

- do produkcji leków - do produkcji żywności - we wszystkich celach - do produkcji paszy do zwierząt nnie popieram

Wykres 2. Wyniki zbiorcze odpowiedzi udzielonych przez respondentów w 2019 r. $(n=699)$ 


\subsection{Wyniki zbiorcze odpowiedzi z podziałem na wiek}

Większość badanych z czterech przedziałów wiekowych wyróżnionych na potrzeby niniejszych badań spotkała się z terminem GMO. Spośród nich najliczniejszą grupę (95\%) stanowili ankietowani w wieku 20-35 lat, a najmniej liczną (5\%) - osoby powyżej 6o. r.ż. Ten sam trend wiekowy zaobserwowano w odpowiedzi na pytanie o zgodę na uprawę roślin GMO w rolnictwie: w grupie między 20. a 35. r.ż. aż 61\% respondentów było bardzo przychylnych takim uprawom, natomiast tylko 14\% było na „tak” wśród osób powyżej 6o. r.ż.

Silną istotność statystyczną w zakresie różnic $(\mathrm{p}<\mathrm{o}, \mathrm{O} 1)$ zaobserwowano w odpowiedziach udzielanych na temat obaw przed negatywnymi skutkami spożywania produktów zawierających GMO, głównie u osób powyżej 6o. r.ż. (69\%) i osób między 35. a 60. r.ż. (64\%). Tymczasem najliczniejszy odsetek osób (61\%), które nie podałyby swoim dzieciom produktów spożywczych zawierających GMO, odnotowano w grupie poniżej 20. r.ż., ale nie był to wynik istotny statystycznie. Tylko w jednej z grup (w wieku od 35 do 60 lat), powyżej 50\% osób zwracało uwagę na oznakowanie kupowanych produktów pod kątem zawartości GMO. Wszystkie grupy wiekowe wykazały poparcie dla korzystania z leków wyprodukowanych drogą inżynierii genetycznej, a spośród nich statystycznie istotne odpowiedzi ( $<$ o,o1) na "tak" odnotowano wśród osób poniżej 20. r.ż., a najmniejsze u osób powyżej 6o. r.ż.

\subsection{Wyniki zbiorcze odpowiedzi z podziałem na wykształcenie}

Z terminem GMO spotkało się 95\% osób z wykształceniem wyższym oraz $97 \%$ uczniów i studentów. Najbardziej przychylna stosowaniu upraw roślin GMO była grupa uczniów i studentów (67\%) oraz osób z wykształceniem wyższym (56\%). Wszystkie zaobserwowane różnice w opiniach nt. GMO u osób o różnym stopniu wykształcenia nie były statystycznie istotne ( $\mathrm{p}>\mathrm{0}, 05)$.
Obawa przed negatywnymi skutkami spożywania produktów zawierających GMO była obserwowana głównie wśród osób z wykształceniem średnim (58\%) oraz wśród 4.2\% uczniów i studentów. Wszystkie grupy nie zwracały większej uwagi na oznakowanie kupowanych produktów pod kątem zawartości GMO, ale 50\% wśród osób z wykształceniem wyższym wyznało, że zwraca uwagę na etykiety zamieszczone na produktach. Za to, bez względu na wykształcenie, każda grupa społeczna (powyżej 50\% ankietowanych) chętnie skorzystałaby z leków wyprodukowanych drogą inżynierii genetycznej. Osoby z wykształceniem podstawowym w równym stopniu popierały i były przeciwne jakimkolwiek zastosowaniom GMO w różnych sektorach życia i przemysłu, studenci zaś i osoby z wykształceniem średnim i wyższym wyrażali poparcie (odpowiednio $38 \%, 48 \%$ i $49 \%$ ) dla GMO stosowanych do produkcji leków.

\subsection{Wyniki zbiorcze odpowiedzi z podziałem na miejsce zamieszkania}

Aż 92\% mieszkańców wsi i 95\% mieszkańców miasta spotkało się z terminem GMO. Mieszkańcy wsi podchodzili jednak bardziej ostrożnie do zgody na uprawę modyfikowanych odmian roślin i tylko $25 \%$ było na „tak”, a 24\% na „nie”, większość zaś (51\%) nie miała zdania na ten temat. Wśród mieszkańców miasta aż $62 \%$ było przychylnych takim uprawom, 34\% nie popierało upraw GMO i tylko 4\% nie miało żadnego zdania na ten temat.

Różnice w odpowiedziach odnośnie obawy przed negatywnymi skutkami spożywania produktów zawierających GMO były statystycznie istotne $(\mathrm{p}<\mathrm{o}, \mathrm{o1})$ i wykazały większe obawy wśród osób zamieszkujących tereny wiejskie (67\%), niż wśród mieszkańców miast (49\%). Również różnice w opinii ankietowanych nt. podania swoim dzieciom produktów spożywczych zawierających GMO istotnie różniły się między miastem a wsią (p < o,o01), gdzie 51\% mieszkańców miast i odpowiednio 70\% mieszkańców wsi było temu przeciwnych. Większość (67\%) 
mieszkańców wsi zwracała uwagę na oznakowanie kupowanych produktów GMO, choć wśród mieszkańców miast czyniło tak mniej osób (49\%). Ten sam odsetek osób przychylnych stosowaniu leków wyprodukowanych drogą inżynierii genetycznej pochodził ze wsi i z miasta (67\%), dla p < o,o1.

Podobny odsetek osób ze wsi (23\%) i miasta (25\%) nie miał zdania nt. zastosowania GMO w różnych sektorach życia i przemysłu, zaś 19\% mieszkańców wsi i 17\% mieszkańców miasta było przychylnych wszelkim zastosowaniom GMO. Ciekawostką jest, że tylko niewielka część mieszkańców wsi popierała użycie GMO do produkcji pasz (2\%) i żywności (1\%).

\section{Podsumowanie ankiet}

W naukach biotechnologicznych łączą się różne dziedziny badań, począwszy od nauk biologicznych po nauki medyczne, w celu otrzymania organizmów o nowych, korzystnych cechach. Za szybkim postępem w osiągnięciach biotechnologii podąża opinia społeczna, która ulega stałej zmianie w miarę upływu lat. Począwszy od przystąpienia Polski do UE, można zauważyć pewne trendy w postrzeganiu produktów GMO przez konsumentów. I tak, jeszcze w 2000 r. tylko 53\% Polaków deklarowało swą obawę względem produktów modyfikowanych genetyczne, postrzegając je jako zagrożenie dla środowiska i zdrowia człowieka, ale już w 2005 r. obawy miało więcej $65 \%$ ankietowanych (Twardowski 2008, 181-184). Badania przeprowadzone przez Rzymskiego i Królczyk (2016, 689697) wśród 1021 respondentów o średniej wieku 32 lata, z udziałem 69\% kobiet i 31\% mężczyzn, w większości mających wyższe i średnie wykształcenie oraz zamieszkujących miasto, pokazują, że w 2016 r. około 53\% ankietowanych posiadało wiedzę nt. GMO, ale w $60 \%$ było również przeciwnych produkcji żywności GMO w Polsce. Przeprowadzone w 2017 r. badania opinii wśród 361 respondentów (w większości kobiet w wieku od 35 do 60 lat, głównie z miasta) wykazały dobrą znajomość terminu GMO u 96\% ankietowanych, ale obawy przed produktami modyfikowanymi genetycznie w żywności sięgały aż 70\% (Nowakowska 2018, 12-15). W niniejszych badaniach z 2019 r., przeprowadzonych na grupie 699 osób (57\% kobiet, $64 \%$ w wieku od 20 do 35 lat, $51 \%$ z wykształceniem wyższym i w większości zamieszkujących miasto), 94\% ankietowanych spotkało się $\mathrm{z}$ terminem GMO i $48 \%$ nie miało obaw przed spożyciem takich produktów, ale już $55 \%$ ankietowanych nie podałoby ich swoim dzieciom.

W porównaniu do średnich wartości krajowych GUS z 2019 r. (https://stat.gov. pl), dane demograficzne respondentów ankietowanych w 2019 r. prawie dokładnie odzwierciedlają podział społeczeństwa polskiego według płci, wykształcenia na poziomie średnim oraz grupy osób znajdujących się w przedziale wieku 20-59 lat. W porównaniu do średnich krajowych w 2019 r., badaniu ankietowemu poddano o 30\% więcej respondentów z wykształceniem wyższym (wg GUS ta grupa stanowi 21\% społeczeństwa), o 15\% więcej studentów (3\% wg GUS) oraz o $23 \%$ więcej mieszkańców miast (60\%). $\mathrm{Z}$ drugiej strony, w ankiecie zabrakło ok. 10\% osób w wieku do 20. r.ż. (18\% wg GUS), 16\% osób w wieku powyżej 6o. r.ż. (21,4\%), 10\% osób z wykształceniem podstawowym (12\%) oraz $23 \%$ osób zamieszkujących wieś (40\%). Otrzymane za pomocą ankiety przeprowadzonej w 2019 r. wyniki można zatem przyjąć za reprezentatywne u wybranych grup społecznych, rozpatrywanych według kryterium płci, wykształcenia i wieku.

Na przełomie lat, wiedza nt. genetycznie modyfikowanych organizmów rośnie, ale obawy przed produktami modyfikowanymi genetycznie nadal utrzymują się u ponad połowy społeczeństwa, mimo że większość towarowych gatunków GMO (soja, kukurydza, rzepak) są uprawiane z przeznaczeniem na paszę dla zwierząt lub na biopaliwa, a nie do bezpośredniej konsumpcji przez społeczeństwo. Największe poparcie wśród Polaków uzyskiwało zastosowanie GMO w produkcji leków: ok. 45\% w 2016 r. (Rzymski i Królczyk 2016, 689-697), aż 90\% w 2016 r. (Twardowski 2016, 181-188), 38\% w 2017 r. 
(Nowakowska 2018, 12-15) i 47\% w 2019 r. (obecne badania). Porównywalny rozkład procentowy poparcia i sprzeciwu wśród społeczeństwa dla produktów GMO otrzymano w innych krajach Europy, np. we Francji (Bony 2003), Albanii (Dervishi i Bajrami 2020, 13) i Serbii (Majstorović 2020, 32).

\section{Dyskusja - różne aspekty GMO}

Nastawienie polskiego społeczeństwa do produktów GMO jest raczej negatywne, chociaż w uzasadnieniu do noweli ustawy z 2018 r., badania opinii społecznej przeprowadzone w latach 2008-2011 nie wykazały obaw społeczeństwa przed skutkami negatywnego oddziaływania pasz GMO na zdrowie ludzi i zwierząt (Linkiewicz et al. 2012b, 966-981). Niekiedy konsumenci zgłaszają obawy wobec faktu, że produkty GMO mogą wytwarzać oporność na antybiotyki (np. chlorampfenikol), jako pozostałość po wprowadzonych do organizmu docelowego genach markerowych, ale takie ryzyko jest na ogół dokładnie weryfikowane na etapie tworzenia GMO w laboratorium, np. za pomocą testów PCR i real-time PCR, przed jego komercyjnym upowszechnieniem np. w produkcji enzymów spożywczych i paszowych, dodatków i aromatów (Fraiture et al. 2020, 106873).

W przemysłach spożywczym i rolnym, powszechnie stosowane są genetycznie modyfikowane odmiany roślin towarowych. Według danych Statista (2020), największy obszar upraw genetycznie zmodyfikowanych na świecie znajduje się w USA (75 mln hektarów w 2018 r.) i Brazylii (ponad $51 \mathrm{mln}$ ha), zaś najczęściej modyfikowanymi uprawami są: bawełna (80\% upraw), soja (77\%) i kukurydza (30\%). Warto zaznaczyć, że Polsce mimo zakazu upraw gatunków GMO, możliwy jest import produktów zawierających GMO lub powstałych z GMO, które uzyskały pozytywną autoryzację UE i Europejskiego Urzędu ds. Bezpieczeństwa Żywności (EFSA), a dotyczy to głównie transgenicznej kukurydzy, rzepaku, soi, bawełny, buraka cukrowego, a także biomasy (na cele paszowe) wyprodukowanej z GM bakterii i drożdży. Od 1 stycznia 2020, obowiązują w Polsce nowe zasady informowania konsumentów o tym, że nabywane przez nich środki spożywcze są wolne od GMO (Ustawa 2019). Dotyczy to produktów spożywczych, w których zawartość GMO nie przekracza o,1\%, a sama obecność GMO jest przypadkowa lub technicznie nieunikniona. Nowe zasady oznakowania produktów nie dotyczą pasz, które zawierają mniej niż o,9\% GMO.

Na podstawie badań przeprowadzonych przez CBOS w 2013 r., większość Polaków jest przeciwna uprawom roślin modyfikowanym genetycznie oraz nie chce kupować produktów otrzymanych od zwierząt karmionych paszą zawierającą GMO (CEBOS 2013). Wobec wyboru zakupu produktu zawierającego GMO bądź wolnego od GMO, zdecydowana większość (72\%) ankietowanych skłaniała się do zakupu produktu niemodyfikowanego genetycznie i niezawierającego GMO, nawet gdyby był on znacznie droższy (CEBOS 2013).

Za to pozytywne nastawienie społeczeństwa można odnotować w przypadku mikroorganizmów GMO wykorzystywanych do produkcji substancji farmakologicznie czynnych, lub stosowanych w nowoczesnej medycynie ukierunkowanej na terapie genowe (Smorąg i Jura 2000, 413-420; Zhang et al. 2020). Przykładowo, obniżenie ryzyka odrzucenia organu podczas ksenotransplantacji dzięki wyłączeniu genu warunkującego powstawanie antygenu $\alpha 1,3$-galaktozylotransferazy $(\alpha-$ Gal) u zwierzęcia - dawcy organu, jest powszechnie akceptowane przez opinię społeczną (Smorąg et al. 2011, 1-4). Nieco mniej kontrowersji budzi również ostatnio rozwijająca się nowa technika edytowania genomu (tzw. metoda CRISPR/Cas9), która prowadzi wyłącznie do zmian mutacyjnych w wybranych genach organizmu docelowego, a nie do insercji obcych sekwencji DNA do komórek biorcy (Zhang et al. 2020).

Możliwy wpływ upraw zmodyfikowanych genetycznie (GM) na środowisko, w tym szeroko pojęte biocenozy roślin i zwierząt, jest również kontrowersyjnym tematem, często poruszanym w Europie i na świecie. Zezwolenie na eksperymentalne uwalnianie 
GMO do środowiska oraz komercyjne wprowadzanie do obrotu w UE są poddane szczegółowej ocenie. Rynkowa komercjalizacja upraw GMO jest rozpatrywana przez Komisję Europejską na podstawie rozporządzenia WE nr 1829/2003 oraz dyrektywy Parlamentu Europejskiego i Rady 2001/18/ WE z dnia 12 marca $2001 \mathrm{r}$. w sprawie zamierzonego uwalniania do środowiska organizmów zmodyfikowanych genetycznie. W zakresie naukowej oceny ryzyka związanego z produktami GMO, Komisja odwołuje się do opinii niezależnych ekspertów i organizacji międzynarodowych, takich jak EFSA. Przed wydaniem zgody na wprowadzenie GMO do produkcji i obrotu na skalę rynkową, EFSA wymaga m.in. udostępnienia procedury zastosowanej modyfikacji genetycznej, przeprowadzenia analizy ryzyka odrzucenia produktu GMO przez konsumentów oraz przeprowadzenia badań nad nieszkodliwością wyprodukowanego GMO dla środowiska (Nowakowska et al. 2014, 113-115). Badania kontrolne trwają na ogół wiele lat i dotyczą m.in. oceny trwałości konstruktu genowego w modyfikowanych roślinach, oraz oceny ryzyka przenoszenia "nowych” genów między roślinami (transfer horyzontalny), lub przenoszenia genów z roślin, np. do mikroorganizmów glebowych (transfer pionowy). Dodatkowo, szczegółowo analizowany jest wpływ interakcji między roślinami GM a organizmami docelowymi (patogenami lub szkodnikami) na różnorodność biologiczną ekosystemów sąsiadujących z oprawami GMO, oraz wpływ na zdrowie konsumentów (ludzi i zwierząt). W tego typu badaniach, często stosowane są matematyczne modele oceny ryzyka wystąpienia przestrzennych i czasowych skutków GMO w środowisku (EFSA 2010; Żmijewska et al. 2017, 47-55).

Wobec stale zmieniającej się postawy nt. obecności produktów GMO w codziennym życiu społeczeństwa, warto zauważyć, że istnieje duża potrzeba wdrażania programów edukacyjnych przybliżających szerokiemu gronu odbiorców problematykę związaną z GMO tak, aby przedstawić zarówno zalety, jaki i wady, jakie niesie ze sobą współczesna inżynieria genetyczna ukierunkowana na modyfikacje genetyczne roślin, bakterii, grzybów i zwierząt.

\section{Wnioski}

Społeczny odbiór organizmów modyfikowanych genetycznie oraz produktów wyprodukowanych z GMO lub zawierających GMO, stale się zmienia. W porównaniu do poprzednich lat, ogromna większość społeczeństwa (94\%) spotkała się z terminem GMO, lecz nadal zastosowanie GMO w rolnictwie i w przemyśle spożywczym budzi największe obawy w opinii publicznej. $\mathrm{Na}$ podstawie uzyskanych odpowiedzi udzielonych w 2019 r. przez 699 respondentów, można wysunąć następujące wnioski:

1. W przeciwieństwie do mężczyzn, większość kobiet w wieku od 20 do 59 lat obawia się GMO, zwraca większą uwagę na oznakowanie produktów zawierających GMO i nie podałaby ich swoim dzieciom.

2. Osoby w wieku poniżej 20 lat są pozytywnie nastawione do GMO, zaś osoby w wieku powyżej 35 lat najbardziej objawiają się negatywnych skutków spożywania produktów GMO.

3. Większość osób mieszkających na wsi, w tym kobiet i mężczyzn z wykształceniem średnim, obawia się produktów modyfikowanych genetycznie.

4. Niezależnie od płci, opinia mieszkańców miasta była podzielona na dwie prawie równe grupy, zarówno zwolenników jak i przeciwników GMO.

5. Niezależnie od grupy wiekowej i pochodzenia, respondenci z wykształceniem średnim $w$ wieku od 20 do 59 lat, byli pozytywnie nastawieni do korzystania z leków wyprodukowanych drogą inżynierii genetycznej.

6. Na podstawie danych $\mathrm{z}$ ankiet przeprowadzonych w latach $2000-2019$, wiedza polskiego społeczeństwa o GMO rośnie, ale rosną również obawy nt. bezpieczeństwa żywności zmienionej genetycznie, przy stałym poparciu dla 
zastosowania nowoczesnych technologii GMO w sektorze medycznym.

\section{Bibliografia}

Bartoszewski, Grzegorz. 2012. "Regulacje prawne i odbiór społeczny GMO.” W GMO w świetle najnowszych badań, red. Katarzyna Niemirowicz-Szczytt, 123-139. Warszawa: SGGW.

Bony, Sylvie. 2003. "Why are most Europeans opposed to GMOs? Factors explaining rejection in France and Europe." Electronic Journal of Biotechnology 6(1): 7-8.

Boothe, Joseph G., Jillian A. Saponja, and Dana L. Parmenter. 1998. "Molecular farming in plants: Oilseeds as vehicles for the production of pharmaceutical proteins." Drug Development Research 42: 172-181.

CBOS. 2013. Polacy o bezpieczeństwie żywności $i$ GMO. BS/2/2013. Warszawa: CEBOS. Dostęp 5.11.2020. http://www.cbos.pl/SPISKOM. POL/2013/K_002_13.PDF.

Dervishi, Aida, and Ani Bajrami. 2020. "GMOs and genome editing - Public perception and attitude in Albania." In 1st PlantEd Conference Plant Genome Editing - State of the Art edited by Vladislava Galović, 13. Sremski Karlovci: DIV Print.

Dyrektywa 2001 - Dyrektywa 2001/18/WE Parlamentu Europejskiego i Rady Europy w sprawie zamierzonego uwalniania do środowiska organizmów zmodyfikowanych genetycznie i uchylająca dyrektywę Rady 90/220/EWG wraz z późniejszymi nowelizacjami.

Dyrektywa 2015 - Dyrektywa Parlamentu Europejskiego i Rady (UE) 2015/412 z dnia 11 marca 2015 r. w sprawie zmiany dyrektywy 2001/18/WE w zakresie umożliwienia państwom członkowskim ograniczenia lub zakazu uprawy organizmów zmodyfikowanych genetycznie (GMO) na swoim terytorium.

Dyrektywa 2019 - Dyrektywa Komisji UE 2019/782 z dnia 15 maja 2019 r. zmieniająca dyrektywę Parlamentu Europejskiego i Rady 2009/128/WE w odniesieniu do ustanowienia zharmonizowanych wskaźników ryzyka.

EFSA. 2010. "EFSA Panel on Genetically Modified Organisms (GMO). Guidance on the environmental risk assessment of genetically modified plants." EFSA Journal 8(11): 1879.
EFSA. 2011. "EFSA Panel on Genetically Modified Organisms (GMO). Scientific Opinion on application (EFSA-GMO-NL-2008-52) for the placing on the market of herbicide tolerant genetically modified soybean A5547-127 for food and feed uses, import and processing under Regulation (EC) No 1829/2003 from Bayer CropScience." EFSA Journal 9(5): 2147.

Fraiture, Marie-Alice, Marie Deckers, Nina Papazova, and Nancy H.C. Roosens. 2020. "Detection strategy targeting a chloramphenicol resistance gene from genetically modified bacteria in food and feed products." Food Control 108: 106873.

Jefferson, Artrish, Valerie E. Cadet, and Abigail Hielscher. 2015. "The mechanisms of genetically modified vaccinia viruses for the treatment of cancer." Critical Reviews in Oncology/Hematology 95(3): 407-416.

Kamle, Madhu, Pradeep Kumar, Jayanta Kumar Patra, and Vivek K. Bajpai. 2017. "Current perspectives on genetically modified crops and detection methods." Biotech 7(3): 219.

Kleter, Gijs A., and Esther J. Kok. 2010. "Safety assessment of biotechnology used in animal production, including genetically modified (GM) feed and GM animals - a review." Animal Science Papers and Reports 28(2): 105-114.

Kues, Wilfried, and Heiner Niemann. 2004. „The contribution of farm animals to human health." Trends in Biotechnology 22(6): 286-294.

Linkiewicz, Anna, Zbigniew T. Dąbrowski, i Sławomir Sowa. 2012a. "Genetycznie zmodyfikowane rośliny - z laboratorium do praktycznego wykorzystania w europejskim rolnictwie. Część I." Chemik 66(8): 843-855.

Linkiewicz, Anna, Zbigniew T. Dąbrowski, i Sławomir Sowa. 2012b. "Genetycznie zmodyfikowane rośliny - z laboratorium do praktycznego wykorzystania w europejskim rolnictwie. Część II." Chemik 66(9): 966-981.

Liua, Hua, Jinbin Wanga, Peng Li, Lan Bai, Junwei Jia, Aihu Pan, Xuanqi Long, Weidong Cui, and Xueming Tang. 2020. "Rapid detection of P-35S and $\mathrm{T}$-nos in genetically modified organisms by recombinase polymerase amplification combined with a lateral flow strip." Food Control 107: 106775.

Majstorović, Nebojša. 2020. "Purchasing products of gene technology: Psychological factors affecting consumer decision making." In 1st PlantEd 
Conference Plant Genome Editing - State of the Art, edited by Vladislava Galović, 32. Sremski Karlovci: DIV Print.

Małyska, Aleksander, Eliza Lubiatowska-Krysiak, i Tomasz Twardowski. 2012. „Opinia społeczna.” W Aspekty społeczne i prawne biotechnologii, red. Tomasz Twardowski, 217-248. Warszawa: PAN Warszawska Drukarnia Naukowa.

Marris, Claire. 2001. "Public views on GMOs: deconstructing the myths. Stakeholders in the GMO debate often describe public opinion as irrational. But do they really understand the public?" EMBO Reports 2(7): 545-548.

Mathur, Jaideep, and Csaba Koncz. 1998. "PEG-mediated protoplast transformation with naked DNA." In Arabidopsis Protocols, edited by José M. Martínez-Zapater, and Julio Salinas, 267-276. Totowa: Humana Press.

Nester, Eugene. 2008. "Agrobacterium: the natural genetic engineer 100 years later." Online. APSnet Features. https://doi.org/10.1094/ APSnetFeatures-2008-0608.

Nowakowska, Justyna Anna, Małgorzata Sułkowska, and Tomasz Oszako. 2014. "Environmental risk assessment of Genetically Modified Plants (GMO) - challenges and approaches." Folia Forestalia Polonica, Series A 56(2): 113-115.

Nowakowska, Justyna Anna. 2018. "Świadomość społeczna o organizmach genetycznie modyfikowanych (GMO)." AURA 7: 12-15.

Pniewski, Tomasz, Józef Kapusta, Piotr Bociąg, Jacek Wojciechowicz, Anna Kostrzak, Michał Gdula, Olga Fedorowicz-Strońska, Piotr Wójcik, Halina Otta, Sławomir Samardakiewicz et al. 2011. "Lowdose oral immunization with lyophilized tissue of herbicide-resistant lettuce expressing hepatitis B surface antigen for prototype plant-derived vaccine tablet formulation." Journal of Applied Genetics 52(2): 125-136.

Prawo.pl. 2020. "Nowe zasady znakowania żywności „bez GMO” już obowiązują.” Dostęp 24.07.2020. https://www.prawo.pl/biznes/zywnosc-bez-gmood-poczatku-2020-r-nowe-zasady-znakowania,497017.html.

Rozporządzenie 2003 - Rozporządzenie (WE) nr 1829/2003 Parlamentu Europejskiego i Rady z dnia 22 września 2003 r. w sprawie genetycznie zmodyfikowanej żywności i paszy.
Rzymski, Piotr, and Aleksandra Królczyk. 2016. "Attitudes toward genetically modified organisms in Poland: to GMO or not to GMO?" Food Security 8(3): 689-697. https://doi.org/10.1007/ s12571-016-0572-z.

Smorąg, Zdzisław, and Jacek Jura. 2000. "Animal Biotechnology - methods, practical application and potential risks." In Progress in Biotechnology 17 - Food Biotechnology, edited by Stanislaw Bielecki, Johannes Tramper, and Jacek Polak, 413-420. Amsterdam-Lausanne-New York-Oxford-Shannon-Singapore-Tokyo: Elsevier.

Smorąg, Zdzisław, Ryszard Słomski, Jacek Jura, Daniel Lipiński, i Maria Skrzyszowska. 2011. "Transgeniczne świnie jako dawcy tkanek i narządów do transplantacji u ludzi." Przeglad Hodowlany 11: $1-4$.

Statista.com. 2020. "Genetically modified (GM) crops.” Accessed 24.07.2020. https://www.statista.com/study/22433/ genetically-modified-gm-crops-statista-dossier/.

Twardowski, Tomasz. 2008. "Societal attitudes regarding GM food: the case of Poland within the European Union." Environmental Biosafety Research 7: 181-184.

Twardowski, Tomasz. 2016. „Rzeczywistość XXI wieku-GM żywność." Nauka 2: 181-188.

Ustawa 2019 - Ustawa z 13 czerwca 2019 r. o oznakowaniu produktów wytworzonych bez wykorzystania organizmów genetycznie zmodyfikowanych jako wolnych od tych organizmów (t.j. Dz. U. z 2019 r. poz.1401).

Wprost.pl. 2020. „Polscy konsumenci nie chcą produktów z GMO. Od nowego roku produkty muszą być lepiej oznakowane." Dostęp 24.07.2020. https:// www.wprost.pl/ekologia/10286155/polscy-konsumenci-nie-chca-produktow-z-gmo-od-nowego-roku-produkty-musza-byc-lepiej-oznakowane.html. Zhang, Zhen, Jiping Wang, Chunyan Li, Wenyue Xue, Yazhi Xing, and Feng Liu. 2020. "Gene therapy development in hearing research in China." Gene Therapy 27(7): 349-259. https://doi.org/10.1038/ s41434-020-0177-1.

Żmijewska, Ewelina, Sławomir Sowa, and Magdalena Żurawska-Zajfert. 2017. "Principles of environmental risk assessment of genetically modified plants in European Union." Progress in Plant Protection 57(1): 47-55. 